\title{
Microstructures of co-axially folded vein segments and crenulation cleavage: Evidence for dissolution phenomena in the Chamba Thrust Sheet, western Himalayas
}

\author{
Department of Geology, University of Delhi, Delhi-110007, India. Email: bksharma@du.ac.in> and <Ambhola@du.ac.in>
}

The metasediments in the Chamba region experienced three phases of deformation: $D F_{1}, D F_{2}$ and $D F_{3}$. Folded quartz veins are co-folded with the $F_{2}$ crenulation folds. Their geometric and tectonic significance is studied by microstructures and shortening adjacent to the discrete crenulation cleavage, $S_{2}$. Microstructures of folded vein segments, their geometric changes and truncation to cleavage $\left(S_{2}\right)$ are mainly due to pressure-solution phenomena and the estimated volume loss from reconstructed vein segments range from 16 to $25.5 \%$, which is closely related to volume decrease (26\%) calculated from the polydeformed slates of North Wales areas.

\section{Introduction}

Elaborated analysis of natural and experimental deformation products coupled with field relationships and theoretical modeling of deformation process has led to the recognition of microstructures as important deformation features to study mechanisms operating during tectonic events (Schmid, 1982; Borradaile et al., 1982; Zwart, 1962; Passchier and Trouw, 1998). Microstructures and textures developed at different stress levels in different kinematic frameworks (Simpson and Schmid, 1983; Passchier and Simpson, 1986), have aided in interpreting the dynamics of deformation, metamorphism and fluid processes (Durney, 1972; Gray, 1978; Etheridge et al., 1983 and McCaig, 1987; Mackentelow, 1994; Starkey, 2002).

We attempted to determine the mechanism for crustal shortening in the Chamba thrust sheet (Tethyan sequence) through microstructures. Most of the Western Himalayan workers emphasize thrust propagated folding or imbricate thrusting as main mechanism for contraction or crustal shortening of Tethyan Himalayan folded thrust belt (Corfield and Searle, 2000; Ratschbacher, 1999; Wiesmayr and Grasemann, 2002). Further, based on balanced model of NW Himalayas (from Shimla to Spiti) the amount of shortening of the folded thrust belt has been calculated to be $30 \%$ (Wiesmayr and Grasemann, 2002).

The green-schist-facies metasedimentary rocks in the Chamba region are polydeformed and show three phases of deformation (Thakur, 1998; Bhola and Sharma, 1986; Sharma, 1999; Sharma, et al., 2003). Folded quartz veins are well developed in the metapelites of the Chamba sequence (Middle Proterozoic). These veins were developed synchronously together with the $F_{2}$ crenulation folds and are very common in the Phukri slates or Pukhri Formation (Middle Proterozoic) in the Chamba area (Bhola, 1992; Sharma, 1999).
The present paper examines the relationship between microstructures of folded veins and coeval crenulation folds $\left(F_{2}\right)$ to illustrate the deformation mechanism responsible for their segmentation. The study presented here also investigates whether there is any relationship between vein segmentation and crenulation-cleavage $\left(S_{2}\right)$ development in the slate-phyllite sequence of Chamba thrust sheet.

\section{Geological setting}

The Chamba region forms a part of the wide longitudinal valley that lies between the Zanskar and Dhauladhar Ranges in the north and south, respectively (Figure 1). The valley trends NW-SE and is considered to be of tectonic origin (Gansser, 1964; Wadia, 1957). The southern part of the longitudinal valley is known as the Chamba val-

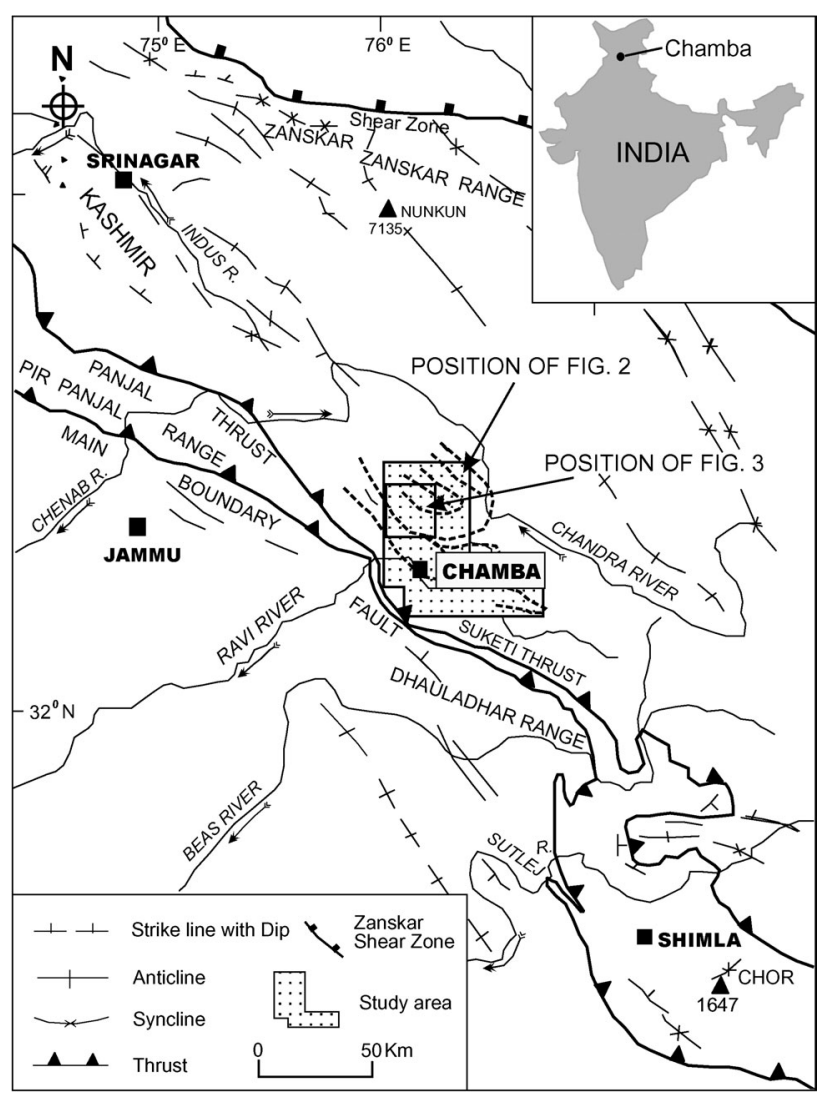

Figure 1 Map of the western Himalayas showing regional structural features (after Gansser, 1964). 
ley and the northwestern part is known as Kashmir valley (Figure1). The stratigraphic sequence in the Chamba-Bharmaur syncline, a part of the Chamba nappe (Thakur, 1998), belongs to PrecambrianñUpper Palaeozoic age and is thrust over the Lesser Himalayan Formations to the south along the Panjal thrust. These rocks represent the southern extension of the Tethyan facies of the Zanskar Himalayan sequence. Chamba sequence represents the southerly extension of the Kashmir sequence, which is equivalent to Tethyan Himalayan Sequence (Rattan, 1973; Kapoor, 1977; Fuchs \& Linner, 1995).

The rocks of the Chamba region are regionally folded into the south-verging Chamba and Bhramaur overturned syncline with a NW-trending axial trace (Sharma, 1999; Sharma and Bhola, 2002; Sharma et. al., 2003; Figure 2). The northern limb of the syncline dips SW and rests over the high-grade metamorphic rocks belonging to the Higher Himalayan Crystallines. The lithologic units involved in the syncline are shown in Figure 2 and summarized in Table 1.

The rocks of the Chamba region are grouped into (1) the lower and (2) the upper sequence (Rattan, 1973). The lower sequence rests on the Middle Proterozoic Bhalai Formation. The Bhalai Formation is conformably overlain by the Chamba Formation, which consists of grey, buff, olive stained slates, phyllite and psammites. The Chamba formation is followed in succession upwards by the Pukhri Formation, which consists of dark grey, carbonaceous, thinly bedded slates and phyllite along with subordinate quartzite and is overlain by Manjir formation, which constitutes the uppermost part of the lower sequence in the Chamba region. The Manjir Formation consists of grey and purple thinly bedded slate that at places contains pebbly horizon. The upper sequence is represented by the lower Salooni Formation, also known as the Katarigali Formation (unfossiliferous, Table 1) and is overlain by the Saho Volcanics and the upper Salooni Formation (containing lower Permian plant fossils (Srivastava and Kumar, 1992). The upper Salooni formation is over-
Table 1 Generalized stratigraphic column of the Chamba region, western Himalaya (after Rattan, 1973; Ghosh, 1980 and personal communication by GSI, Faridabad, 1999).

\begin{tabular}{|c|c|c|c|c|}
\hline \multicolumn{2}{|c|}{$\begin{array}{l}\text { SYMBOLIC REPRESENTATION } \\
\text { OF FORMATION }\end{array}$} & AGE & THICKNESS & LITHOLOGY \\
\hline & $\begin{array}{l}\text { KALHEL } \\
\text { LIMESTONE }\end{array}$ & Lr. Triassic & $400 \mathrm{~m}$ & $\begin{array}{l}\text { Grey and yellow dolomitic limestones } \\
\text { with interbedded white and grey } \\
\text { orthoquartzites in the upper part and } \\
\text { numerous stems and osccles of } \\
\text { crinoids in the lower part. }\end{array}$ \\
\hline & $\begin{array}{l}\text { UPPER } \\
\text { SALOONI }\end{array}$ & $\begin{array}{l}\text { M. Permian } \\
\text { to } \\
\text { U. Permian }\end{array}$ & $400 \mathrm{~m}$ & $\begin{array}{l}\text { Limestones interbedded with grey } \\
\text { calcareous slates / calcareous phyllites } \\
\text { /quartzites. }\end{array}$ \\
\hline & $\begin{array}{l}\text { SAHO } \\
\text { VOLCANICS }\end{array}$ & M. Permian & 10-50m & $\begin{array}{l}\text { Metavolcanics of basaltic and andesitic } \\
\text { composition }\end{array}$ \\
\hline & $\begin{array}{l}\text { KATARIGALI } \\
\text { (Lr. Salooni) }\end{array}$ & $\begin{array}{l}\text { Up. Carbo. } \\
\text { To } \\
\text { M. Permian }\end{array}$ & $800 \mathrm{~m}$ & $\begin{array}{l}\text { Dark grey and carbonaceous pyritous } \\
\text { slates,containing black phosphatic } \\
\text { nodules/siliceouscrystalline limestone } \\
\text { /carbonaceous phyllite/phyllitic } \\
\text { quartzites. } \\
\end{array}$ \\
\hline & $\begin{array}{l}\text { MANJIR } \\
\text { CONG. }\end{array}$ & L. Cambrian & $1000 \mathrm{~m}$ & $\begin{array}{l}\text { Grey and purple metamorphosed } \\
\text { pebbly mudstones paraconglomerates } \\
\text { with inter-calated bands of grey slates, } \\
\text { consisting conglomeretic flysch. }\end{array}$ \\
\hline & $\begin{array}{l}\text { PUKHRI } \\
\text { SLATE }\end{array}$ & M. Proterozoic & $2000 \mathrm{~m}$ & $\begin{array}{l}\text { A rapid alteration of slates or phyllites } \\
\text { and metasiltstone-metagreywacke, } \\
\text { constituting shaly flysch. }\end{array}$ \\
\hline 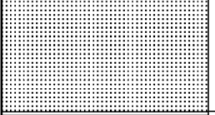 & $\begin{array}{l}\text { CHAMBA } \\
\text { FORMATION }\end{array}$ & M. Proterozoic & $3500 \mathrm{~m}$ & $\begin{array}{l}\text { Monotonous alteration of metagrey- } \\
\text { wacke and slate, forming sandy flysch. }\end{array}$ \\
\hline & $\begin{array}{l}\text { BHALAI } \\
\text { FORMATION } \\
\text { (Dalhousie Granite) }\end{array}$ & M. Proterozoic & $3500 \mathrm{~m}$ & $\begin{array}{l}\text { Greyish green, talcose phyllites and } \\
\text { schists, garnet-biotite schist, micaceous } \\
\text { quartzites and interbedded with bands } \\
\text { of dark grey crystalline limestone with } \\
\text { associated Dalhousie granite }\end{array}$ \\
\hline
\end{tabular}

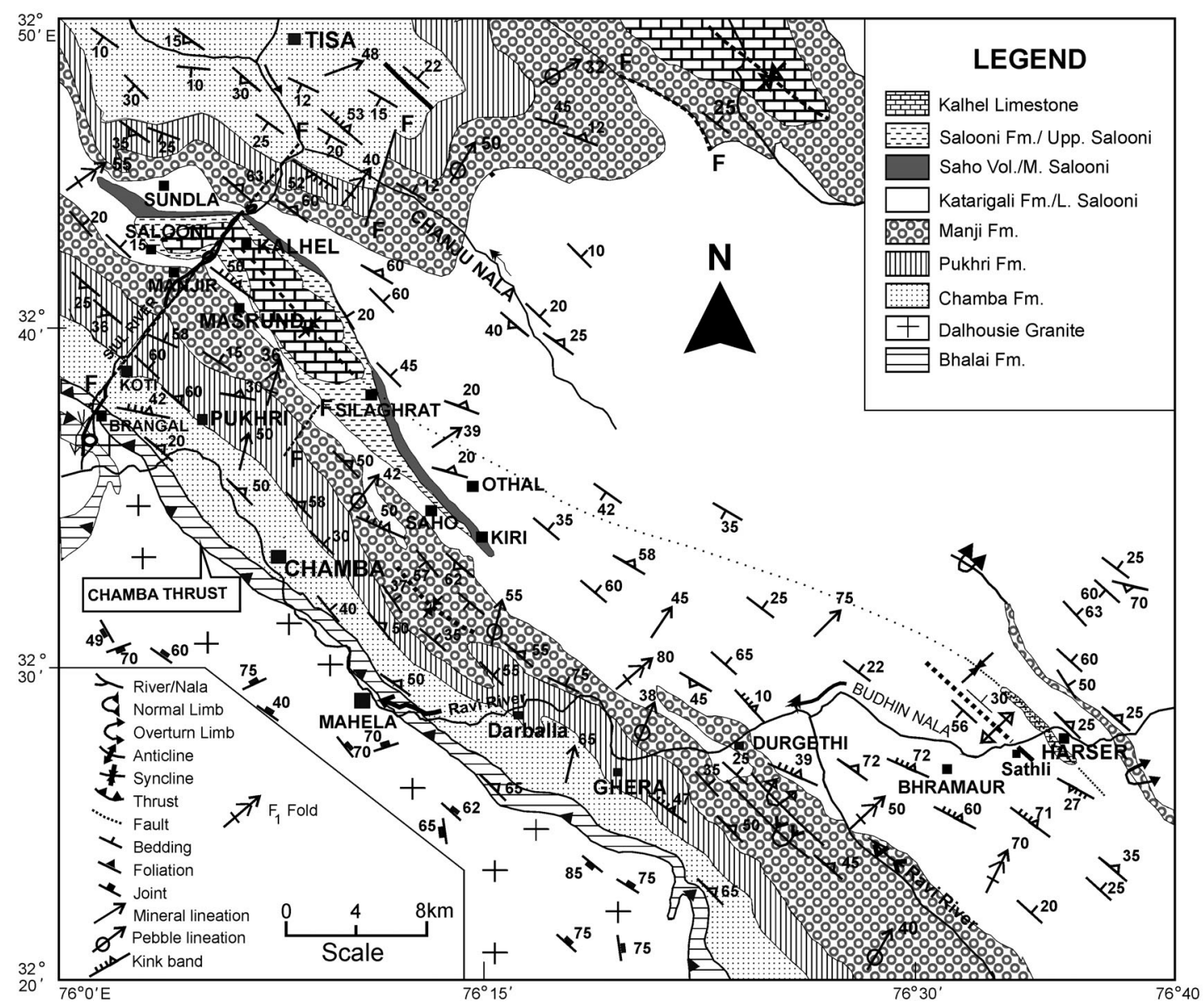

Figure 2 Geological map of Chamba region, Western Himalaya (Sharma et al. 2002). 


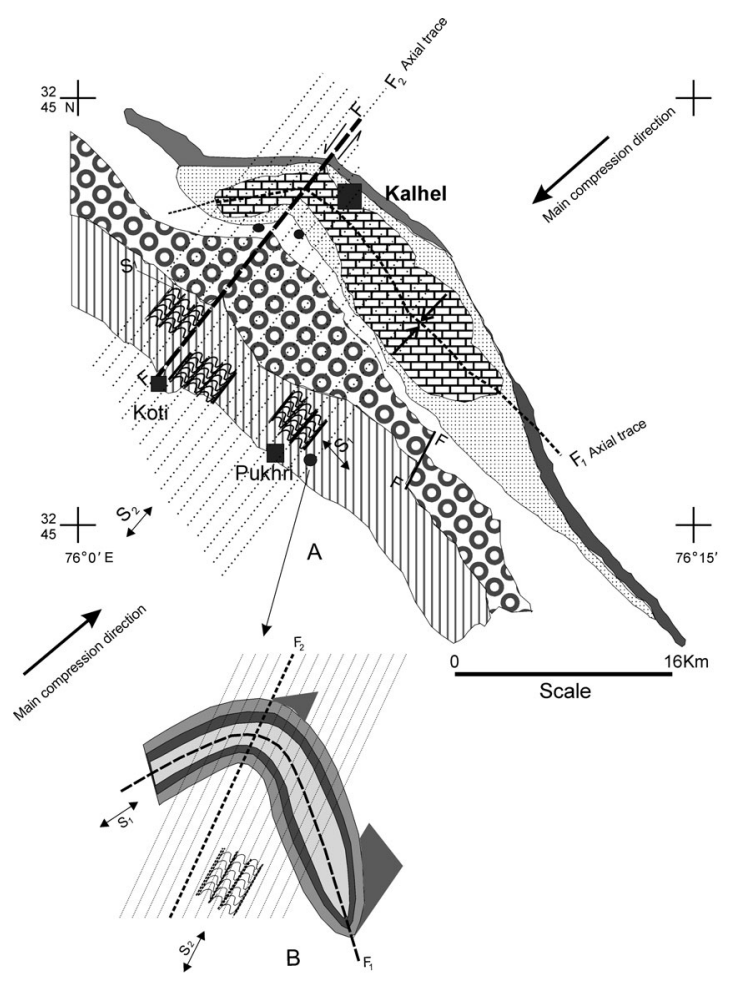

Figure 3 (A) Schematic representation of the development of $F_{1}$ and $F_{2}$ folds and the associated faults. The $S_{2}$ fabric in the form of crenulation cleavage transects $S_{1}$ at high angle. Important to note that the co-folded vein segments produced due to pressure solution effects in the more stress areas around Pukhri-Koti. (B) Schematic diagram of main refolding pattern between $F_{1}$ and $F_{2}$.

lain by the (Early to Middle Permian) Kalhel limestone that forms the youngest formation in the area. It is mainly crystalline dolomitic limestone of varigated colours, interbedded with grey coloured quartzites in the upper part. The basal part of the formation is characterised by stems and osicles of crinoids (McMahon, 1883). Their exits unconformable relationship between the upper and lower sequence but both are regionally folded by Chamba-Bharmaur syncline, whose core is represented by Kalhel limestone of Lower Triassic age (Table 1).

\section{Structures}

The mesoscopic fabric imprinted on the rocks of the Chamba nappe are related to three phases of deformation $\mathrm{DF}_{1}, \mathrm{DF}_{2}$, and $\mathrm{DF}_{3}$ identified on the basis of overprinting of foliations, superposition of structural elements of one style and orientation on those of another style of orientations. Each deformation has its own geometric characteristics, which help in assigning structures to a particular phase of deformation. The second $F_{2}$ generation folds almost coaxially refolded tight isoclinal F1 folds and show type III interference pattern (Ramsay, 1967; Figure 3A and 3B). In such outcrops $F_{2}$ folds deform $S_{1}$ cleavage and have coevally developed, $S_{2}$ crenulation cleavage transecting at high angle but the $F_{1}$ and $F_{2}$ fold axes show partial parallelism. The superimposition of $F_{3}$ folds on $F_{2}$ folds has resulted in the formation of type I interference resulting in the formation of dome and basin (Ramsay, 1962, 1967).

\section{Microstructure}

The microstructures of the first-phase microfolds $\left(\mathrm{F}_{1}\right)$, extensional structures and the pervasive cleavage $\left(\mathrm{S}_{1}\right)$ have been affected by subsequent deformation phases. The $\mathrm{F}_{1}$ micro folds are affected by open to tight nature of $F_{2}$ micro folds associated with crenulation cleavage. The $S_{1}$ fabric, concordant quartz veins and quartz lenticles are co-folded by micro $\mathrm{F}_{2}$ folds (Figures $4 \mathrm{~A}$ and $4 \mathrm{~B}$ ). Contrasting fold morphology of micro $\mathrm{F}_{2}$ folds is seen in the quartzo-phyllite. Microfolds $F_{2}$ are associated with crenulation cleavage of both zonal and discrete crenulation cleavage. Discrete cleavage is more prominent and occurs in the form of thin differentiated discontinuities at time and irregular, truncate the initial crenulated fabric and co-folded quartz veins. There is marked change in the mineralogy in cleavage zone and microlithon (cf Gray, 1978). Mostly, the cleavage consists of tiny flakes of phyllosilicates, dimensionally oriented ferruginous / carbonaceous matter. Quartz is conspicuously lacking in these zones. Discrete crenulation cleavage sometimes manifests as en-chelonally arranged discontinuities in argillaceous layers in the region where there is increase in quartz proportion. The discrete cleavage terminates at quartz rich areas and develops in phyllosilicate proportions.

The micro $\mathrm{F}_{2}$ folds in folded quartz vein are bordered by discrete cleavage $\mathrm{S}_{2}$ (Figures 5A and 5B). The quartz near the hinges of folded quartz vein is polygonal but slightly flattened in the limb regions. The microstructural fabrics of these veins show that their geometric modification is related to the zones where discrete crenulation cleavage has formed. The geometry of the folded veins whether tight to open has bearing on the concentration of the crenulation cleavage. The tight geometry veins within argillaceous layers, alternating with quartz-rich layers show good development of the cleavage on the steeper limbs of the folds in incompetent layers. The co-axially folded veins at these locations show thinning, tapering or offsets (Figures 6A and 6B). The amount of thinning of limbs or
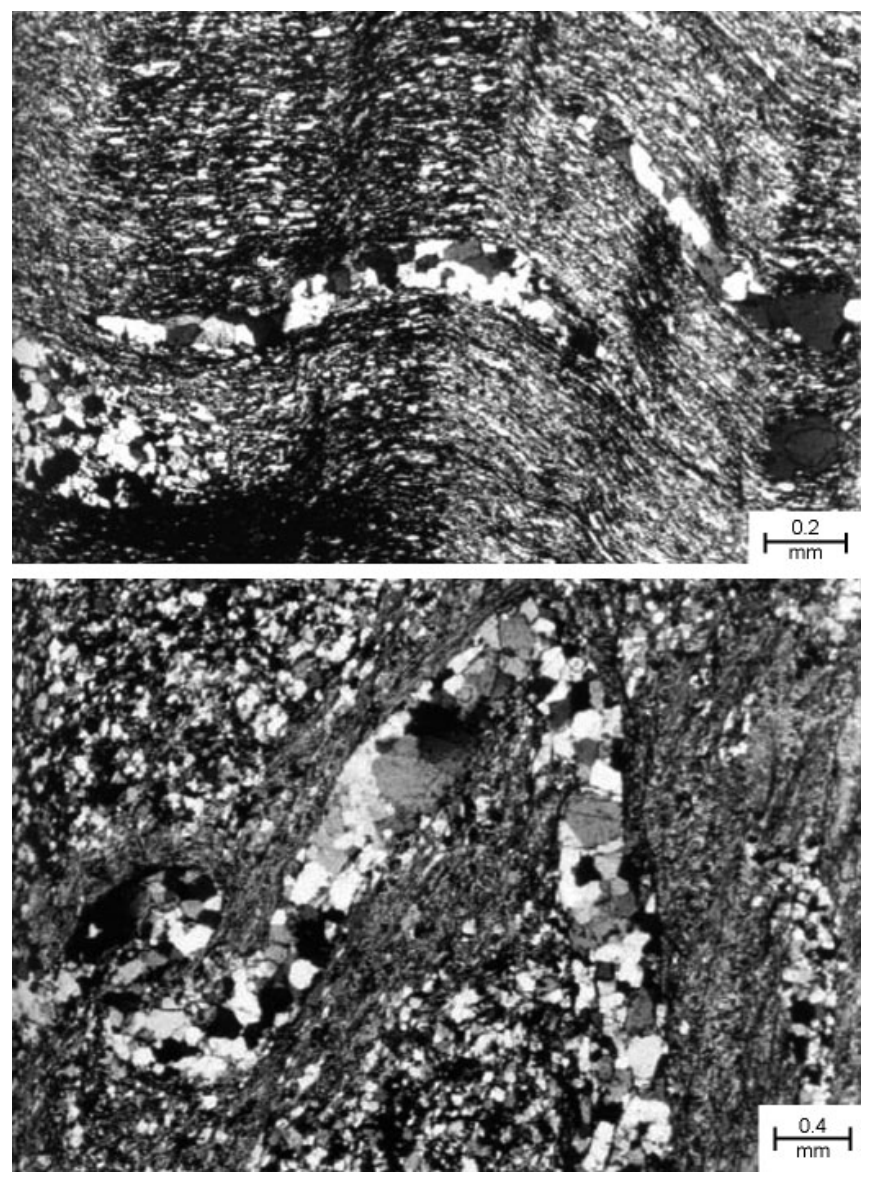

Figure 4 A (above)-Photomicrographs showing quartz lenticles along $S_{1}$ fabric refolded by microfolds $\left(F_{2}\right) . B$ (below)-Micro $F_{2}$ fold shown by quartz vein in Pukhri slate-phyllite sequence. The development of incipient crenulation cleavage is noticed in phyllosilicate rich area and pressure solution effects at the limbs of the fold. 

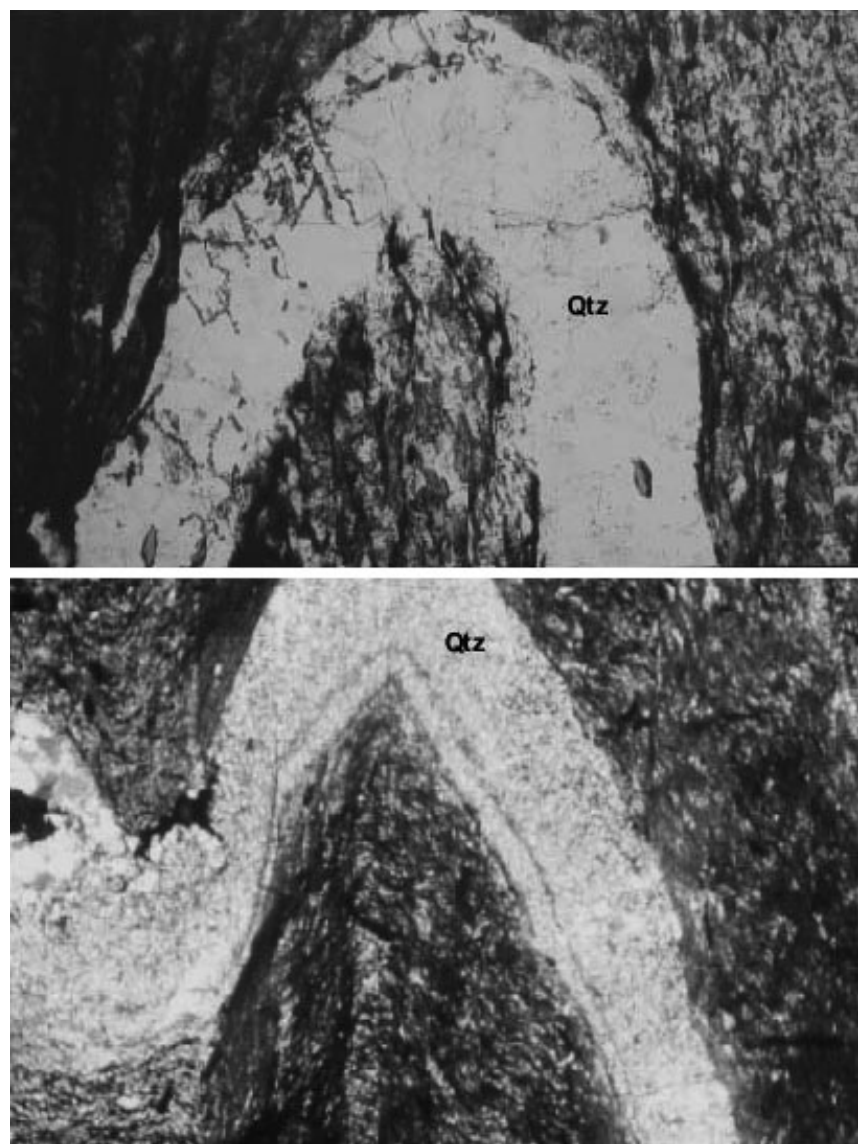

Figure 5 A (above)-Photomicrograph showing partial solution truncation of folded vein limb and the development of crenulation cleavage. B (below)-Partial solution thinning of folded vein limb and the development of crenulation cleavage.

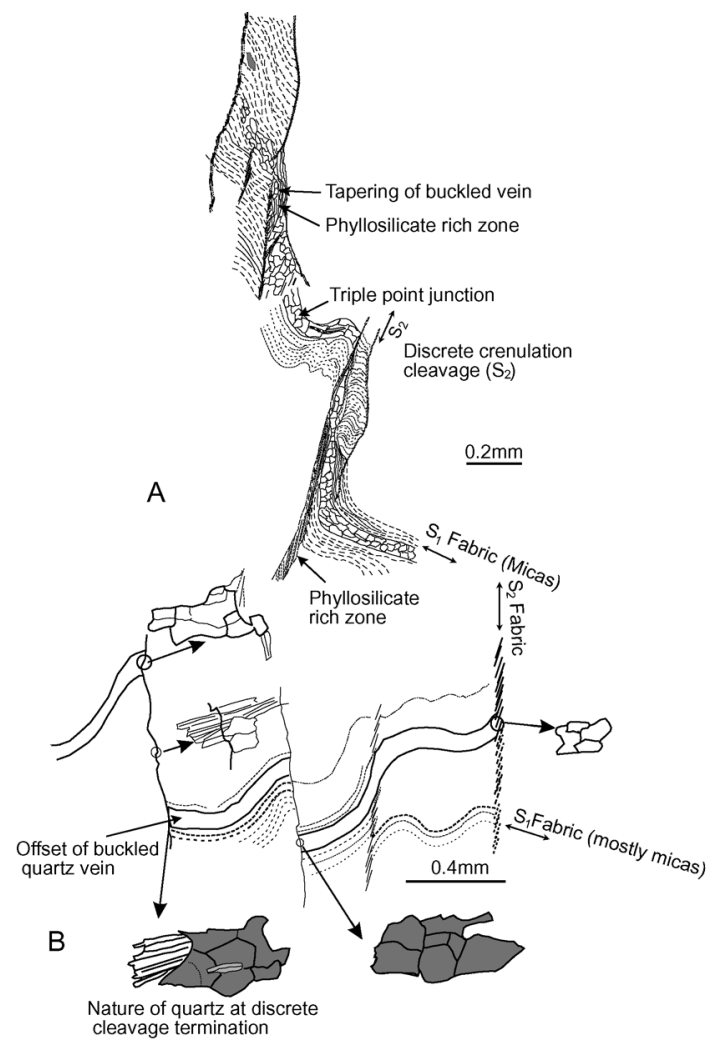

Figure 6 Sketches from micro sections showing microstructure of folded veins. detachment of veins is directly related to the marked frequency of the cleavage. Microfolds with open geometry affecting thin as well as thick argillaceous layers show development of cleavage to lesser extent. These observations suggest that the tight geometry folded veins affecting anisotropic layers are significant in the localization and the frequency of the crenulation cleavage. Furthermore, quartz in veins along crenulation cleavage show straight to sutured boundaries respectively. Micas do not show any features like bent cleavage, kinking or slip along cleavage and neither quartz shows strong undulose extinction, deformation bands or sub grain development or fracturing which could suggest of some movement along the crenulation cleavage plane. Instead, almost complete absence of quartz in the discrete cleavage zone may be attributed to dissolution and migration leaving the cleavage zone richer in the phyllosilicates. This leads to the complete mineral redistribution across the microfolds and development of new layering coincided with their limbs. The microstructures of crenulation cleavage clearly showed that dominant mechanism of their development was microfolding and pressure solution deformation. Pressure solution and solution transfer of material is dominant at diagenetic to low grade metamorphic conditions, which is the case in the Chamba region, where fluids are abundant and crystal lattice is under high stress (William, 1972; Cosgrove, 1976; Gray \& Durney, 1979, Knipe, 1980, Wheeler, 1987, Passchier \& Trouw, 1998). Starkey (2002) also based on modal and chemical analyses to study of crystallographic orientation of quartz grains has shown significant differences in the microlithons and zones of cleavage. In the cleavage zone there is reduction in quartz and enrichment of mica also accompanied by enrichment in $\mathrm{TiO}_{2}$, $\mathrm{Al}_{2} \mathrm{O}_{3}, \mathrm{Fe}_{2} \mathrm{O}_{3}, \mathrm{MnO}, \mathrm{MgO}, \mathrm{K}_{2} \mathrm{O}$ and $\mathrm{P}_{2} \mathrm{O}_{5}$ and depletion of $\mathrm{SiO}_{2}$, $\mathrm{CaO}$ and $\mathrm{Na}_{2} \mathrm{O}$. The support to this mechanism is further strengthened by microstructures of folded veins.

The tightly folded quartz veins show more dissolution effects as compare to open fold geometry (Figures 4B, 5A and 5B). The limb of the folded vein show solution truncation, tapering and finally complete dissolution (Figures 4B, 6A, 7A and 7B). The quartz in the vein is recrystallised, unstrained and shows triple junction and solu-
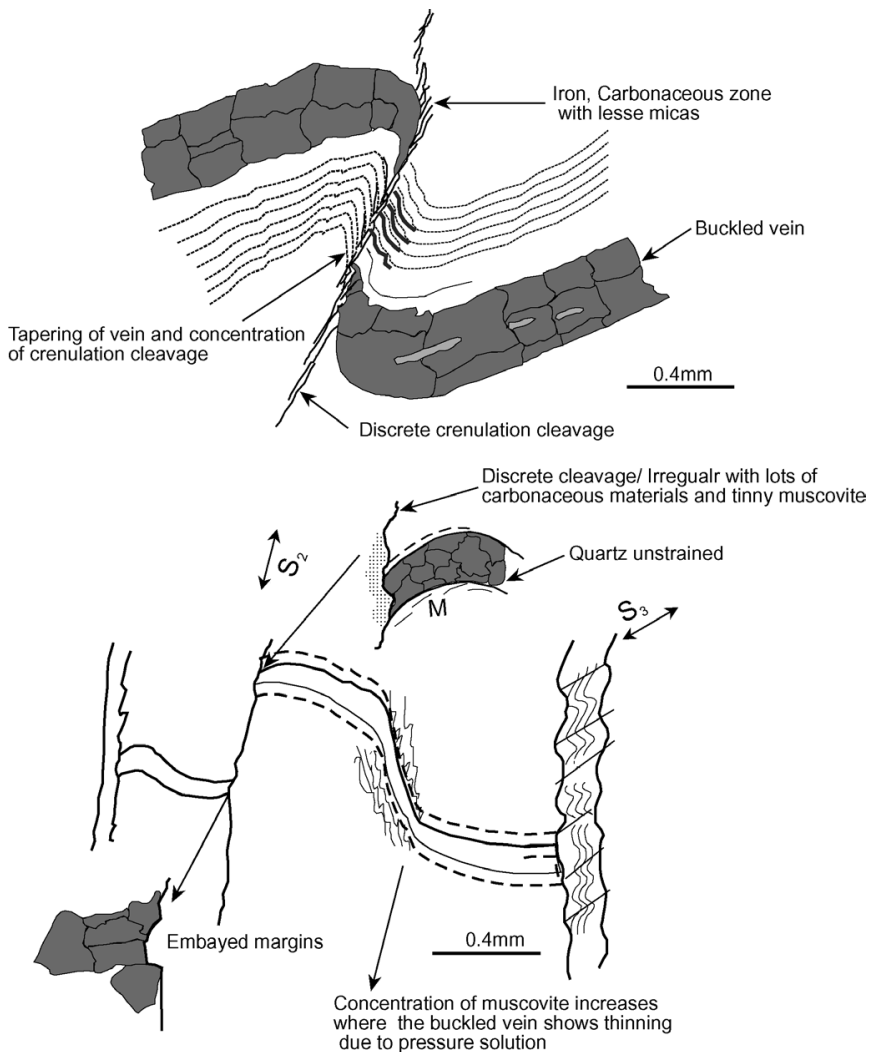

Figure 7 Sketches from micro sections showing microstructure of folded veins. 
tion truncation, even in the thinned portions. The layer thinning and detachment leads to the ëoffsetí of veins along cleavages (Figures 6B and 7B). Where such features are observed the intensity and frequency of the crenulation cleavage increases and is related to the extent to which folded veins show thinning, tapering of layers and detachment. If it was ductile shearing the quartz grains along thinned limb should display grain elongation parallel to stretching direction. No marked difference in the shape, size and structure of the quartz grains along thinned and truncated limbs, compared to those along limbs with uniform thickness. Truncated segments of folded vein showed much greater concentration of phyllosilicates in phyllite matrix at point of vein termination. The removal of quartz, features attributed to solution processes in rocks are accompanied by a significant reduction in volume of mass. The cleavage zones as dark seams are completely devoid of quartz which otherwise occurs in microlithon. These features suggest change in the chemistry along the zones, which are related to their development. The quartz veins show offsets as well as thinning of limbs along the crenulation cleavage and where such features are observed, intensity and frequency of the cleavage increases. Truncated segments show no evidence of cracking or fracturing at their terminations but commonly have sutured, smooth and curved boundaries (Figures 6A, 7A). No localized intracrystaline deformation is observed at these terminations. Quartz grains immediately adjacent to the truncated segment of quartz veins show no increase in undulose extension, development of define lamellae or other change in grain substructure.

Phyllosilicate shows no observable increase in intracrystalline deformation such as translation reflecting basal-plane slippage and kinking. No noticeable size and shape changes of phyllosillicates in the cleavage compared to those along the primary or existing slaty cleavage. Phyllosilicates defining the discrete cleavage zones are more closely packed and show a much greater degree of preferred orientation than those in the inter cleavage domains.
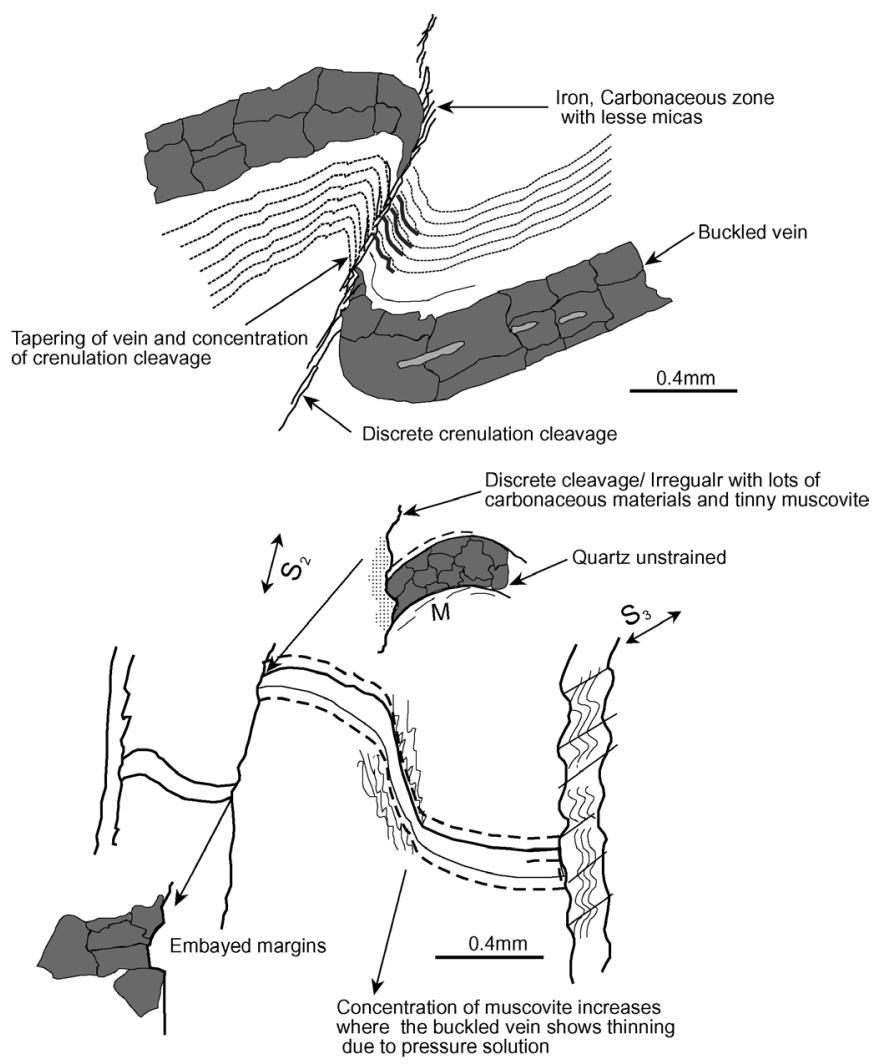

Figure 8 Dissolved vein segments and reconstructed sections of folded quartz vein from crenulated Pukhri slates. Estimates of parameters shown in inset and calculated value for each veins are shown in table 2 (vein traced from different thin sections of folded veins in crenulation folds on projection microscope).

\section{Estimation of parameters from vein segments}

As it is evident from the observations described above, the vein segments represent stages of partial dissolution of the folded vein. With the increase in stress, the vein geometry will be modified and the limb of folded veins may show pronounced dissolution, which leads to its apparent offset. By visualizing different stages of attenuation by the removal of the material from one set of the limbs, the vein segments have been reconstructed. The assumptions applied in reconstructing vein are as suggested by Gray (1979): (1) Folded quartz veins show parallel-fold geometry (Class IB geometry). (2) Dissolution of material took place along the fold, which occurs along $S_{2}$ elongation direction. (3) Deformation resulting into $F_{2}$ folds was of constant plane with co-axial increments layer shortening normal to $S_{2}$ cleavage was concomitant with extension. (4) Lack of significant shear displacement along $S_{2}$ folded quartz veins in crenulated fabrics.

The dissolved veins were reconstructed with these assumptions and traced as parallel folds (Figure 8 ). These have parallel geometry in non-truncated veins. From the reconstructed veins, estimates of shortening due to folding, pressure solution and total shortening for particular vein segments (Figure 8) have been calculated and results are shown in Table 2. By studying the estimated parameters from vein segments, it is observed that shortening strain is directly related to the amount of pressure solution or volume decrease the rock has undergone. The maximum values of volume decrease are up to $25.5 \%$. This is very close to the values obtained by Starkey (2002) from polydeformed slates in the North Wales.

Table 2 Calculated $\varepsilon_{T}$ total shortening, $\varepsilon_{B}$ fold shortening, $\varepsilon_{P}$ pressure solution shortening and the ration of fold and pressure solution shortening $\varepsilon_{B} / \varepsilon_{P}$.

\begin{tabular}{ccccc}
\hline & $\mathrm{V}_{1}$ & $\mathrm{~V}_{2}$ & $\mathrm{~V}_{3}$ & $\mathrm{~V}_{4}$ \\
\hline $\boldsymbol{\varepsilon}_{\mathbf{T}}$ & $62.3 \%$ & $34.48 \%$ & $62.29 \%$ & $52.33 \%$ \\
$\boldsymbol{\varepsilon}_{\mathbf{B}}$ & $49.38 \%$ & $21.90 \%$ & $49.93 \%$ & $32.1 \%$ \\
$\boldsymbol{\varepsilon}_{\mathbf{P}}$ & $25.5 \%$ & $16.00 \%$ & $24.68 \%$ & $21.7 \%$ \\
$\boldsymbol{\varepsilon}_{\mathbf{B}} / \boldsymbol{\varepsilon}_{\mathbf{P}}$ & 1.33 & 1.368 & 2.02 & $1.80 \%$ \\
\hline
\end{tabular}

\section{Conclusions}

Microstructural study of co-axially folded veins associated with crenulation folds $\left(\mathrm{F}_{2}\right)$ in the Chamba region lend strong support for pressure solution as one of the dominant mechanism responsible for their microfold fabrics. The crenulation cleavage and its frequency is related to the tightness of the folded veins. The folded quartz veins show solution effects along cleavage zone viz. thinning, sutured and solution truncations, tapering and offset of layers without any evidence of shearing. From the foregoing, it could be stated that the geometric changes in folded vein segments and their sharp truncation to the discrete crenulation cleavages are related to the dissolution phenomena with volume decrease between the range of $16 \%$ to $25.5 \%$ in the cleavage zones in the Chamba thrust sheet.

\section{Acknowledgements}

Authors are grateful to An Yin, UCLA, USA for his thoughtful comments and suggestions, which have considerably improved the quality of this paper. Authors are thankful to Department of Geology, University of Delhi for laboratory facilities and AMB thanks to John G. Ramsay for extending laboratory facilities, ETH Zurich, Switzerland. 


\section{References}

Bhanot, V. B., Goel, A. K., Singh, V. P., and Kwatra, S. K., 1979, Rb-Sr radiometric studies for the Dalhousie and Rohtang areas, Himachal Pradesh: Current Science, v. 44, pp. 219-220.

Bhola, A. M., and Sharma, Y., 1986, Deformation and strain history of rocks around Chamba, Himachal Pradesh: Current Science, Geology v. IX, Himalayan Thrust and associated rocks, Saklani, P. S. (Eds.). pp. 167193.

Bhola, A. M., 1992, Crenulation cleavage development in pukhri formation of Chamba area, Western Himachal Pradesh, India: v. 39, pp. 17-27.

Borradaile, G. J., Bayly, M. B., and Powell, C. M. A., 1982, Atlas of deformational and metamorphic rock fabrics: Springer, Berlin Heidelberg New York.

Corfield, R. I and Searle M. P., 2000, Crustal shortening across the north Indian continental margin, Ladakh, NW India, In Tectonics $f$ the Nanga Parbat Syntaxis and the Western Himalaya, edited by P. J. Treloar, M. P. Searle and M. Q. Jan, Geol. Soc. Spec. Publ., v. 170, pp. 395-410.

Cosgrove, J, W., 1976, The formation of crenulation cleavage. Journal Geological Society: London, v. 132, pp. 155-178.

Durney, D. W., 1972, Solution transfer, an important geological deformation mechanism: Nature v. 235, pp. 315-317.

Fuchs, G., and Linner, M., 1995, Geological traverses across the Western Himalaya $\tilde{n}$ A contribution to the geology of eastern Laddakh, Lahaul and Chamba: Jahrbuch Geologisschen Bundesanstalt, Vienna, v. 138, pp. 655-685.

Etheridge, M. A., Wall, V. J., Cox, S. F. and Vernon, R. H., 1983. Role of the fluid phase during regional metamorphic deformation: Metamorphic Geology, v. 1.pp. 205-226

Gansser, A., 1964, Geology of the Himalayas. Wiley and Sons, New York, 289p.

Ghosh, D.K., 1980, Stratigraphy of Dhauladhar range in the Chamba district, Western Himachal Himalaya; In K. S. Valdiya and S. B. Bhatia (Eds.), Stratigraphy and correlation of Lasser Himalayan Formations, Hindustan Publishers, Delhi. pp. 126-138.

Gray, D. R., 1978, Cleavage in deformed psammitic rocks from Southeastern Australia: their nature and origin: Bulletin of Geological Society of America, v. 89, pp. 577-590.

Gray, D .R., 1979, Microstructures of crenulation cleavages: an indicator of cleavage origin: American Journal of Science, v. 279, pp. 97-128

Gray, D. R., and Durney, D. W., 1979, Crenulation cleavage differentiation: Implication of solution deposition processes: Journal of Structural Geology, v.1(1), pp. 73-80.

Kapoor, H. M., 1977, Pastannah section, Kashmir, with special reference to iOphiceras bed of Middlemiss: Journal Palaeontological Society of India, Orlov. Em. V. 20, pp. 339-347.

Knippe, R. J., 1989, Deformation mechanismsñrecognition from natural tectonites: Journal of Structural Geology, v. 11, pp. 249-272.

Mancktelow, N. S., 1994, On volume change and mass transport during the development of crenulation cleavage: Journal of Structural Geology, v. 16, pp. 1217-1232.

McMohan, C. A., 1883, Some notes on the Geology of Chamba: Records of Geological Survey of India, v. 16, pp. 35-42.

McCaig, A. M., 1987, Deformation and fluid rock interaction in metasomatic dilatant shear bands: Techtonophysics, v. 135, pp. 121-132.

Passchier, C. W., and Trouw, R. A. J., 1998, Microtectonics: Springer ñ Verlag. 1-289.

Passchier , C. W., and Simpson, C., 1986, Porphyroclast systems as kinematic indicators: Journal of Structural Geology, v. 8, pp. 831-844.

Ramsay, J. G., 1962, The geometry of conjugate kink systems: Geological Magazine, v. 99, pp. 516-526.

Ramsay, J. G., 1967, Folding and Fracturing of rocks: McGraw Hill New York, pp. 568.

Ratschbacher, L., W. Frisch, G. Liu and C. Chen, 1994, Distributed deformation in southern and western Tibet during and after the India-Asia collision, Jour. Geophys. Res., v. 99, pp. 19917-19945.

Rattan, S. S., 1973, Stratigraphy and sedimentation of the Chamba area, Western Himachal Pradesh: Himalayan Geology, v. 3, pp. 231 - 248.

Schmid, S. M., 1982, Microfabric studies as indicators of deformation mechanisms flow laws operative in mountain building: In: Hsu KJ (ed) Mountain building processes. Academic Press, London, pp. 95-110.

Simpson, C., and Schmid, S. M., 1983, An evolution of criteria to determine the sense of movement in sheared rocks: Bulletin Geological Society of America, v. 94, pp. 1281-1288.

Sharma, B. K., 1999, Movement pattern and movement sequence in the rocks of the Chamba region, Western Himalaya, H. P. India: Ph. D. Thesis. University of Delhi, Delhi, pp. 1-198.
Sharma, B. K., and Bhola, A. M., 2002, Movement pattern and movement sequence in the rocks of the Chamba nappe, Western Himalaya, India: Journal of Asian Earth Sciences, v. 20, no. 4a (Special abstract volume, 17th HKTW), pp. 41-43.

Sharma, B. K., Bhola, A. M., and Scheidegger, A. E., 2002, Neotectonic Activity in the Chamba Nappe of the Himachal Himalaya: Jointing control of the drainage patterns. Geol. Soc. India, v. 61, pp. 159-169.

Srivastava, D. K., and Kumar, G., 1992, On the ocurrence of plant remance from lower Permian rocks of Chamba Bhadarwah area, Himachal Pradesh, India: Journal Palaeontological Society of India, v. 37, pp. 103107.

Starkey, J., 2002, Chemical changes and the development of quartz preferred orientation in zones of crenulation cleavage, Anglesey: Journal of Structural Geology, v. 24, pp. 1627-1632.

Thakur, V.C., 1998, Structure of the Chamba Nappe and position of the main central thrust in Kashmir Himalaya: Journal of Asian Earth Science, v 16, no. 2-3, pp. 269-282.

Wadia, D. N., 1957, Geology of India: 3rd edition, Mcmillan and Co. London. pp. 536

Wheeler, J., 1987, The determination of true shear senses from the deflection of passive markers in the shear zones: Journal Geological Society of London, v. 144, pp. 73-77.

Williams, P. F., 1972, Development of metamorphic layering and cleavage in low grade metamorphic rocks at Bermagin, Australia: American Journal of Science, v. 272, pp. 1-47.

Zwart, H. J., 1962, On the determination of polymetamorphic mineral associations, and its application to the Bosost area (Central Pyrenees): Geology Rundschau, v. 52, pp. 38-65.

Wiesmayr, G. and Grasemann, B., 2002, Eohimalayan fold and thrust belt: Implications for the geodynamic evolution of the NW-Himalaya (India). Tectonics, v. 21(6), pp.1058,

Sharma B. K., working as a thrust belts of Himalayas. Department of Geology, University Delhi University in 1977. He has

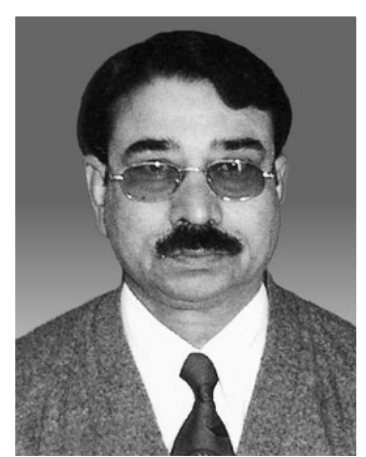
Research Associate in the University of Delhi received his $B$. Sc. and $M$. Sc. degree from Patna University and PhD degree in Structural Geology from Department of Geology, University of Delhi, India in 2000. He has worked as a visiting scientist Igeologist in Physical Research Laboratory, Ahmedabad in 2001-2002. His research was focused on tectonics, microstructures, earthquakes, neotectonics for the last 10 years and presently working on active tectonics and monazite dating of active

A. M. Bhola is a Professor at of Delhi, India. He received PhD at worked on structural and metamorphic aspects in parts of Protrusion Delhi folded belt and in Chamba region, Western Himalaya for the last 28 years. Presently his interest is in resurgent tectonics in the men-

tioned areas.

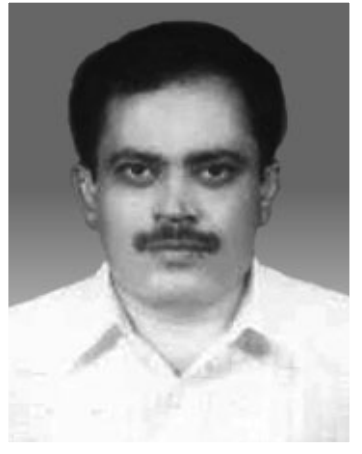

